\title{
In-vitro Screening of Fungicides against Fusarium oxysporum f. sp. ciceri causing Chickpea Wilt in District Meerut Uttar Pradesh
}

\author{
Vikram D. Singh ${ }^{1 *}$, Shyam Singh ${ }^{1}$, Dhirendra $\operatorname{Singh}^{2}$, Shikha $\operatorname{Raghav}^{1}$ and Soni $^{1}$ \\ ${ }^{1}$ Department of Botany, Meerut College, Meerut (U.P.), India \\ ${ }^{2}$ KVK, Ambala (HR), India \\ *Corresponding author
}

\section{A B S T R A C T}

Keywords

Chickpea,

Fungicide,

Fusarium and wilt

Article Info

Accepted:

08 December 2020

Available Online:

10 January 2021
Chickpea wilt caused by $F$. oxysporum f. sp. ciceri. Total Six fungicides (two systemic, two non-systemic and two combi-fungicides) viz., Carbendazim, Propiconazole $25 \%$ EC, Chlorothalonil 75\% WP, Copper oxychloride 50 WP, Carbendazim 12\% + Mancozeb 63\% and Carboxin $37.5 \%$ + Thiram 37.5\%, respectively at three different concentration (each @ 500, 1000, 1500 ppm).Other then all, only one combi-fungicide viz., Carbendazim 12\% + Mancozeb $63 \%$ and one from systemic Carbendazim from said groups were found much more effective against test pathogen at $1500 \mathrm{ppm}$. They was inhibited the fungal growth most satisfactory from others during that test, it range was recorded 95.00 and 94.44 per cent inhibition over control, respectively. Chlorothalonil 75\% WP (Kavach) was the least $(90.00 \%)$ effective fungicides. were found to inhibiting the growth of the test pathogen (Fusarium oxysporum f. sp. ciceri) under in-vitro conditions.

\section{Introduction}

In India chickpea (Cicer arietinum L.) variously known as Gram or Bengal gram. Pulse crops play an important role in Indian agriculture, besides being rich in protein. Fusarium wilt is one of the major diseases of chickpea and they were found that at national level the yield losses up to the tune of 60 per cent. According to the (Arunodhyan et al., 2014) they were stated that $F$. oxysporum f. sp. ciceri infects chickpea at seedling as well as at flowering and pod forming stage, with more incidence at flowering and pod filling stage if the crop is subjected to sudden temperature rise and water stress. According to Maitlo et al., (2014) they were evaluated fourteen fungicides against chickpea wilt pathogen in in- vitro with five different concentrations ranging from $1-1000 \mathrm{ppm}$. Among these only Carbendazim and Thiophanate-methyl were found as the most effective at all concentrations used. Other fungicides like Aliette, Nativo, Hombre-excel and Dividend star were found to be moderately effective. Whereas, remaining fungicides were ineffective against the Fusarium spp. causing chickpea wilt.

As accordingly Ravichandran and Hegde (2015) both was evaluated under in-vitro efficacy of fungicides against $F$. oxysporum $\mathrm{f}$. 
sp. ciceri causing wilt of chickpea and reported that among combi products, Carbendazim $12 \%+$ Mancozeb $63 \%$ (SAAF) was effective at all concentrations $(0.1,0.2$ and $0.3 \%)$ with cent percent inhibition and least inhibition $(21.85 \%)$ was recorded in Zineb $68 \%$ + Hexaconazole 4 $\% \mathrm{WP}$ (Avatar) @ $0.1 \%$ concentration. In contact fungicides, Copper oxy chloride was effective with $90.0 \%$ inhibition @ $0.3 \%$ concentration and minimum inhibition (44.58 $\%)$ was in Zineb @ $0.1 \%$ concentration. Among systemic fungicides Carbendazim and Tebuconazole recorded cent per cent inhibition at all concentrations tested $(0.015$, 0.075 and $0.1 \%$ ) whereas less inhibition $(82.08 \%)$ was in the Difenconazole @ $0.1 \%$.

Similarly results was founded by SumanPatra and Mohan Kumar Biswas (2016) evaluated ten fungicides viz., Carbendazim, Azoxystrobin, Propiconazole, Thiophanate Methyl, Mancozeb, Chlorothalonil, Copper oxy chloride, Carbendazim + Mancozeb, Tebuconazole + Tryfloxystrobin, Hexaconazole+ Zineb at three different concentrations (each @ 500, 1000, 1500 ppm) against $F$. oxysporum f. sp. cicerisand reported that Carbendazim, Propiconazole, and two combination products i.e. (Carbendazim +Mancozeb) and (Tebuconazole + Trifloxystrobin) completely inhibited the mycelial growth of fungus at 1500 ppm concentration followed by Thiophanate Methyl (96.67 \% inhibition) and least inhibition 76.67 per cent by Copper-oxy chloride.

Test pathogen: The Fusarium oxysporum is a saprophyte or a heterotroph in nature they can easily obtain theirfood from organic matter through decomposing method. They are filamentous and belong to the division Ascomycota, class Sordariomycetes, order Hypocreales and family Nectriaceae. They are typically produce microconidia and macroconidia as well as mycelia and chlamydospores that serve as propagules in infected chickpea plant.

Wilt: Yellow dry leaves are defoliated; marginal necrosis of infected leaves is also seen. Reddish to black discoloration of the xylem vessels are seen inside the infected plant near by ground stem as a line or dots in cross section. Roots of wilted plants turn black and decompose in later stage and ultimately dry up.

\section{Materials and Methods}

Total Six fungicides (two systemic, two nonsystemic and two combi-fungicides) viz., Carbendazim (Bavistin 50WP), Propiconazole 25\% EC (Tilt) , Chlorothalonil 75\% WP (Kavach), Copper oxychloride 50 WP (Blitox-50), Carbendazim 12\% + Mancozeb 63\% (SAAF 75\% WP) and Carboxin $37.5 \%$ + Thiram 37.5\% (Vitavax Power 75\% WP), respectively at three different concentration (each@ 500, 1000, 1500 ppm) was asses for their efficacy against Fusarium oxysporum f. sp. ciceri, through laboratory bio-assay, using poison-food technique (Schmitz, 1930).

\section{By laboratory bio-assay (food poison technique)}

Required concentration of each fungicide were mixed into 2 per cent Potato dextrose agar (PDA) medium, then it was shacked properly, to make it homogenous. Then this homogenised fungicide-mixed medium @ 15 $\mathrm{ml}$ was properly poured in each $90 \mathrm{~mm}$ plastic autoclavable sterilized petri-plates plates. After it was solidified, then with the help of sterilized cork-borer a $5 \mathrm{~mm}$ circular disc was cutted from the 15 days old, pure culture petri-plate, of the test pathogen. Then that disc was placed at the centre of each petriplates. In case of control, serve only PDA poured petri-plate, without mixing of any 
fungicides. After inoculation of disc, all these petri-plates were incubated at $25 \pm 1^{0} \mathrm{C}$ for 14 days.

Each experiments of systemic, non-systemic and combi-fungicides was conducted in completely randomized block (CRD) design. Each fungicides group was contend three treatments included suitable control (without adding any fungicides in the PDA medium).
Total four replications were taken for each fungicide group during this investigation.

All experimental details were as given below.

\section{Experimental details}

Design : CRD

Replication : Four

Treatments : Seven

\section{Treatments details}

\begin{tabular}{|c|c|c|c|}
\hline $\begin{array}{c}\text { Number of } \\
\text { treatment }\end{array}$ & Treatments & Trade names & Details \\
\hline $\mathbf{T}_{\mathbf{1}}$ & Carbendazim 50WP & Bavistin & \multirow{2}{*}{ Systemic } \\
\hline $\mathbf{T}_{\mathbf{2}}$ & Propiconazole 25\% EC & Tilt & \\
\hline $\mathbf{T}_{\mathbf{3}}$ & Chlorothalonil 75\% WP & Kavach & Non-systemic \\
\hline $\mathbf{T}_{\mathbf{4}}$ & Copper oxychloride 50 WP & Blitox-50 & \multirow{2}{*}{ Combi-fungicides } \\
\hline $\mathbf{T}_{\mathbf{5}}$ & Carbendazim 12\%+ & SAAF 75\% WP & \\
\hline & Mancozeb 63\% & Vitavax Power 75\% & \\
\hline $\mathbf{T}_{\mathbf{6}}$ & $\begin{array}{c}\text { Carboxin 37.5\% + Thiram } \\
\text { 37.5\% }\end{array}$ & $\begin{array}{c}\text { WP } \\
\end{array}$ \\
\hline $\mathbf{T}_{\mathbf{7}}$ & Control & & \\
\hline
\end{tabular}

The observation on radial mycelial growth/ colony diameter in millimetre $(\mathrm{mm})$ of the test pathogen (Fusarium oxysporum f. $\mathrm{sp}$. ciceri)was assessing at an interval of 24 hours and continued till untreated plates were fully covered with test pathogen mycelial growth. Per cent mycelial growth inhibition of the test pathogen with the botanicals over the untreated control was calculated by using the formula of (Vincent, 1947).

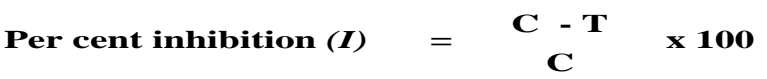

Where,

$\mathrm{I}=$ Per cent inhibition

$\mathrm{C}=$ Growth of the test fungus in untreated control plates.
$\mathrm{T}=$ Growth of the test fungus in treated plates.

* Measuring scale: In millimetre (mm).

\section{Results and Discussion}

The results obtained from the present investigation as well as relevant discussion have been summarized under following heads:

\section{By laboratory bio-assay}

Total Six fungicides (two systemic, two nonsystemic and two combi-fungicides) were asses for their efficacy against Fusarium oxysporum f. sp. ciceri, through laboratory bio-assay, using poison-food technique suggested by (Schmitz, 1930) as described under "Materials and Methods". All treatments were replicated four times. The 
radial growth of the fungus in various treatments was measured and the average diameter of the colony in each plate was calculated for each treatment along with this inhibition per cent over control was recorded. The experiments were conducted during in the years 2019-20. The results are presented in table -1 .

Table.1 Efficacy of fungicides against Fusarium oxysporum f. sp. ciceri through food-poison technique

\begin{tabular}{|c|c|c|c|c|c|c|c|}
\hline \multirow{2}{*}{$\begin{array}{l}\text { Tr. } \\
\text { No. }\end{array}$} & \multirow[t]{2}{*}{ Treatment details } & \multicolumn{3}{|c|}{ Redial diameter $(\mathrm{mm}) *$} & \multicolumn{3}{|c|}{ Per cent Inhibition over control } \\
\hline & & 500 ppm & $\begin{array}{l}1000 \\
\text { ppm }\end{array}$ & $\begin{array}{l}1500 \\
\text { ppm }\end{array}$ & 500 ppm & $\begin{array}{l}1000 \\
\mathrm{ppm}\end{array}$ & $\begin{array}{l}1500 \\
\text { ppm }\end{array}$ \\
\hline $\mathbf{T}_{1}$ & $\begin{array}{l}\text { Carbendazim } \\
\text { (Bavistin 50WP) }\end{array}$ & $\begin{array}{c}6.00 \\
(14.17)\end{array}$ & $\begin{array}{c}5.25 \\
(13.24)\end{array}$ & $\begin{array}{c}5.00 \\
(12.92)\end{array}$ & $\begin{array}{c}93.33 \\
(75.03)\end{array}$ & $\begin{array}{l}94.16 \\
(76.01)\end{array}$ & $\begin{array}{c}94.44 \\
(76.36)\end{array}$ \\
\hline $\mathbf{T}_{2}$ & $\begin{array}{l}\text { Propiconazole } 25 \% \\
\text { EC (Tilt) }\end{array}$ & $\begin{array}{c}8.00 \\
(16.42)\end{array}$ & $\begin{array}{c}7.50 \\
(15.89)\end{array}$ & $\begin{array}{c}6.25 \\
(14.47)\end{array}$ & $\begin{array}{c}91.11 \\
(72.65)\end{array}$ & $\begin{array}{l}91.66 \\
(73.21)\end{array}$ & $\begin{array}{c}93.05 \\
(74.71)\end{array}$ \\
\hline $\mathbf{T}_{3}$ & $\begin{array}{l}\text { Chlorothalonil } \quad 75 \% \\
\text { WP (Kavach) }\end{array}$ & $\begin{array}{l}12.75 \\
(20.92)\end{array}$ & $\begin{array}{l}10.25 \\
(18.67)\end{array}$ & $\begin{array}{c}9.00 \\
(17.45)\end{array}$ & $\begin{array}{c}85.83 \\
(67.88)\end{array}$ & $\begin{array}{c}88.61 \\
(70.27)\end{array}$ & $\begin{array}{c}90.00 \\
(71.56)\end{array}$ \\
\hline $\mathbf{T}_{4}$ & $\begin{array}{l}\text { Copper oxychloride } \\
50 \text { WP (Blitox-50) }\end{array}$ & $\begin{array}{c}11.00 \\
(19.36)\end{array}$ & $\begin{array}{c}8.00 \\
(16.42)\end{array}$ & $\begin{array}{c}7.25 \\
(15.62)\end{array}$ & $\begin{array}{c}87.77 \\
(69.53)\end{array}$ & $\begin{array}{c}91.11 \\
(72.65)\end{array}$ & $\begin{array}{c}91.66 \\
(73.21)\end{array}$ \\
\hline $\mathbf{T}_{5}$ & $\begin{array}{l}\text { Carbendazim } 12 \%+ \\
\text { Mancozeb } 63 \% \\
(\text { SAAF 75\% WP) }\end{array}$ & $\begin{array}{c}5.75 \\
(13.87)\end{array}$ & $\begin{array}{c}5.00 \\
(12.92)\end{array}$ & $\begin{array}{c}4.50 \\
(12.24)\end{array}$ & $\begin{array}{c}93.61 \\
(75.35)\end{array}$ & $\begin{array}{l}94.44 \\
(76.36)\end{array}$ & $\begin{array}{c}95.00 \\
(77.07)\end{array}$ \\
\hline $\mathbf{T}_{6}$ & $\begin{array}{lrr}\text { Carboxin } & 37.5 \%+ \\
\text { Thiram } & 37.5 \% \\
\text { (Vitavax } & \text { Power } & 75 \% \\
\text { WP) } & \end{array}$ & $\begin{array}{c}9.00 \\
(17.45)\end{array}$ & $\begin{array}{c}7.50 \\
(15.89)\end{array}$ & $\begin{array}{c}6.75 \\
(15.05)\end{array}$ & $\begin{array}{c}90.00 \\
(71.56)\end{array}$ & $\begin{array}{l}91.66 \\
(73.21)\end{array}$ & $\begin{array}{c}92.50 \\
(74.10)\end{array}$ \\
\hline $\mathbf{T}_{7}$ & Control & $\begin{array}{c}90 \\
(71.56)\end{array}$ & $\begin{array}{c}90 \\
(71.56)\end{array}$ & $\begin{array}{c}90 \\
(71.56)\end{array}$ & 00.00 & 00.00 & 00.00 \\
\hline \multicolumn{2}{|c|}{ SE(m) } & 0.370 & 0.401 & 0.294 & & & \\
\hline \multicolumn{2}{|c|}{ CD@ $5 \%$} & 1.096 & 1.187 & 0.870 & & & \\
\hline
\end{tabular}

*=Mean of four replications.

*Figure in parentheses indicates transformed values

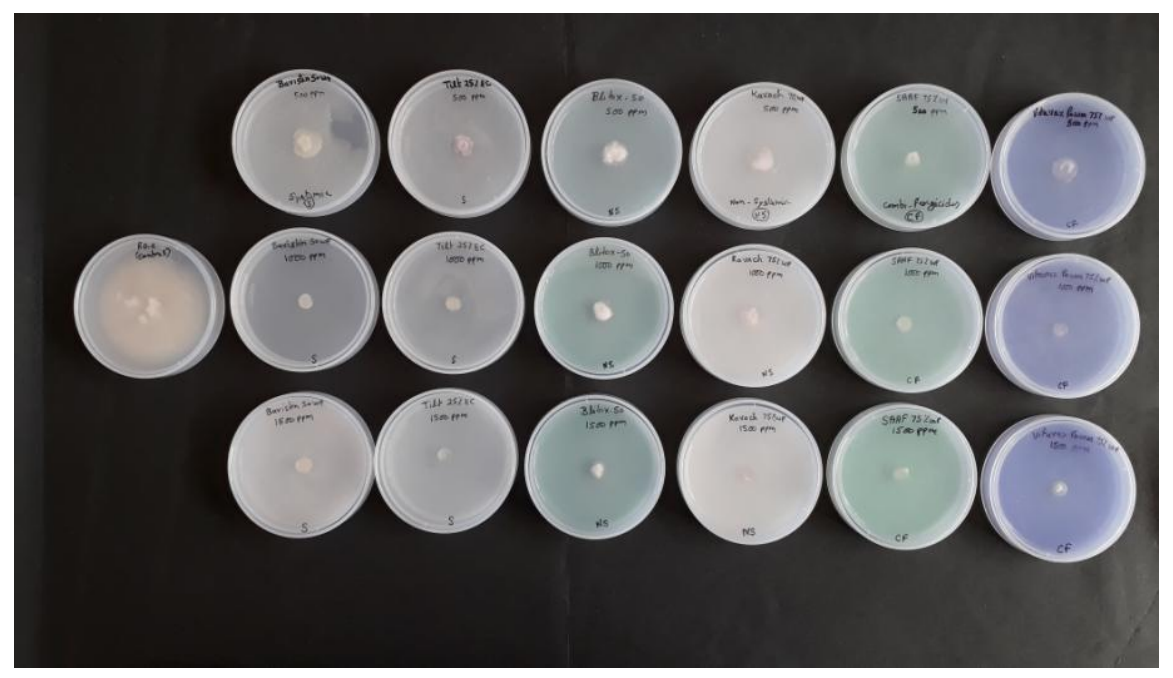


The results presented in table -1 (Fig- A) revealed that groups (systemic, non-systemic and combi-fungicides) of all fungicides were found significantly superior over control at all concentration's. Other then all, only onecombi-fungicide viz., Carbendazim 12\% + Mancozeb $63 \%$ and one from systemic Carbendazim from said groups were found much more effective against test pathogen at $1500 \mathrm{ppm}$.

They was proved to be the most effectiveness against colony growth of the test pathogen under this poison-food technique method, they was inhibited the fungal growth most satisfactory from others during that test, it range was recorded $95.00 \%$ and $94.44 \%$ t inhibition over control, respectively. Chlorothalonil 75\% WP (Kavach) was the least $(90.00 \%)$ effective fungicides. Propiconazole $25 \%$ EC (93.05\%), Carboxin $37.5 \%$ + Thiram 37.5\% (92.50\%) and Copper oxychloride 50 WP (91.66\%) were found to be the next best in inhibiting the growth of the test pathogen (Fusarium oxysporum f. sp. ciceri) under in-vitro conditions.

Similar, fungicide effects of the combifungicides against test pathogen was reported by earlier worker like; Ravichandran and Hegde (2015) they were notice that the combi-product (Carbendazim 12\% + Mancozeb 63\%) as much effective against Fusarium oxysporum f. sp. ciceri it's inhibit almost cent per cent radial growth of test pathogen.

\section{References}

Arunodhayam, K., Reddy, N. P. E. and Madhuri, V. (2014). Pathogenicity and management of Fusarium wilt of chickpea. Cicerarietinum L. - A review.Current Biotica.7(4): 343-358.

Maitlo, S. A., Syed, R. N., Rustamani, M. A., Khuhro, R. D., and Lodhi, A. M. (2014). Comparative efficacy of different fungicides against Fusarium wilts of chickpea (Cicerarietinum L.) Pak. J. Bot., 46(6): 2305-2312.

Schmitz, H. (1930). A suggested taximetric method for food preservation.Indust.andEngin. Anal., 4: 361-365.

SumanPatra and Mohan Kumar Biswas (2016).Efficacy of fungicides for the management of chickpea wilt disease caused by Fusarium oxysporum f. sp. ciceri.Intl. J. Adv. Res. 4(10): 14571461

Ravichandran, S. and Hegde, Y. R. (2015).Evaluation of fungicides against Fusarium oxysporum f. sp. ciceri causing chickpea wilt.Chem. Sci. Rev. Lett. 4(16).1042-1046.

Vincent J. M. (1947). Distortion of fungal hypha in the presence of certain inhibitors.Nature.159: 850.

\section{How to cite this article:}

Vikram D. Singh, Shyam Singh, Dhirendra Singh, Shikha Raghav and Soni. 2021. In-vitro Screening of Fungicides against Fusarium oxysporum f. sp. ciceri causing Chickpea Wilt in District Meerut Uttar Pradesh. Int.J.Curr.Microbiol.App.Sci. 10(01): 747-751. doi: https://doi.org/10.20546/ijcmas.2021.1001.092 